\title{
Clinical Analysis of Miliary Tuberculosis Patients in Our Tertiary Hospital
}

\author{
Yoshihiro Kobashi*, Makoto Kittaka, Keiji Mouri, Shigeki Kato, Mikio Oka \\ Department of Respiratory Medicine, Kawasaki Medical School, Kurashiki, Japan \\ Email: *yoshihiro@med.kawasaki-m.ac.jp
}

How to cite this paper: Kobashi, Y., Kittaka, M., Mouri, K., Kato, S. and Oka, M. (2017) Clinical Analysis of Miliary Tuberculosis Patients in Our Tertiary Hospital. Journal of Tuberculosis Research, 5, 87-93. https://doi.org/10.4236/jtr.2017.51010

Received: February 1, 2017

Accepted: March 26, 2017

Published: March 29, 2017

Copyright (๑) 2017 by authors and Scientific Research Publishing Inc. This work is licensed under the Creative Commons Attribution International License (CC BY 4.0).

http://creativecommons.org/licenses/by/4.0/

\begin{abstract}
Objective: To investigate the clinical characteristics of miliary tuberculosis experienced in our tertiary hospital without a tuberculosis isolation room. Materials and Methods: We obtained a definite diagnosis of tuberculosis for 72 patients in our tertiary hospital between January 2010 and September 2016. There were six patients $(8.3 \%)$ who were diagnosed with miliary tuberculosis following the isolation of Mycobacterium tuberculosis from several organs, and we analyzed the clinical findings. Results: The average age of the six patients with miliary tuberculosis was 74 years old ( 3 males and 3 females). All patients had underlying diseases and immunosuppressive treatment was performed for three patients. The detection methods were based on clinical symptoms such as high fever in all patients. Concerning the laboratory findings, three patients showed a negative or indeterminate response for interferon-gamma release assays (IGRAs). Bronchoscopic examinations were performed for five of six patients soon after admission and a definite diagnosis was obtained. Although treatment according to the American Thoracic Society (ATS) guidelines was performed for all patients, three of the six died due to complications or worsening of miliary tuberculosis. Conclusions: Patients with miliary tuberculosis experienced in a tertiary hospital were frequently detected among patients receiving immunosuppressive treatment for a long time. Because these patients showed a rapid progressive clinical course, it is thought to be important to perform bronchoscopic examination proactively for patients suspected of miliary tuberculosis on radiological findings to make an appropriate early diagnosis and start treatment.
\end{abstract}

\section{Keywords}

Miliary Tuberculosis, Clinical Characteristic, Immunosuppressive Treatment

\section{Introduction}

The incidence of tuberculosis (TB) has declined gradually from 35.4 per 100,000 
people in 1999 to 16.1 per 100,000 people in 2013 in Japan [1]. On the other hand, miliary TB occurs when Mycobacterium tuberculosis (MTB) is spread hematogenously, producing widespread lesions in a patient with reduced immune function. It has been defined that disseminated lesions, 1 to $3 \mathrm{~mm}$ in diameter, involve the lungs and extrapulmonary sites. Miliary TB is a virulent form of TB with a high mortality rate, especially in elderly patients with underlying diseases [2]. In our local tertiary hospital (Kurashiki city, Okayama prefecture, Japan), although TB has also recently declined, patients with miliary TB (the severe type of TB) have sometimes been encountered and showed poor outcomes in our hospital. Therefore, we investigated the incidence of miliary TB and the clinical characteristics of these patients.

\section{Materials and Methods}

Seventy-two patients were diagnosed as TB disease by the isolation of MTB from clinical specimens in Kawasaki Medical School Hospital between January 2010 and September 2016. Of these patients, 6 (8.3\%) were diagnosed with miliary TB. The diagnosis of miliary TB was defined as the presence of bilateral diffuse millet-sized nodules on chest radiography and/or chest computed tomography (CT) as observed by a pulmonary radiologist and the detection of MTB in several organs. We retrospectively investigated the backgrounds, laboratory findings, including interferon- $\gamma$ release assays (IGRAs), radiological findings, length from first visit to diagnosis and outcome, respectively. This study protocol was approved by the Ethical Committee of Kawasaki Medical School.

\section{Results}

There were six patients with miliary TB (8.3\%) among all TB patients in our hospital during the period of this study. The average age of the 6 miliary TB patients was 73 years old ( 3 males and 3 females). All patients had underlying diseases and three of six patients received immunosuppressive treatment for them. All patients had systemic symptoms such as fever and were in poor condition. Most patients, excluding case 6 who was complicated with acute respiratory distress syndrome (ARDS), were suspected of TB disease on admission. The length from admission to diagnosis was comparatively short (average: 6.7days) and all patients were diagnosed by the identification of MTB using a polymerase chain reaction (PCR) method from the bronchoscopic specimens or urine (5 cases), cerebrospinal fluid ( 2 cases), and blood (1 case), respectively (Table 1 ).

The main laboratory findings of the patients with miliary TB showed lymphocytopenia, hypoproteinemia and hypoalbuminemia in most of them. A tuberculin skin test (TST) did not show a weak positive response in one of three patients in whom we could perform it. On the other hand, a QuantiFERON TB-Gold In-tube (QFT-IT) test showed a positive response in three patients, but was negative for one and indeterminate for two. A T-SPOT showed a positive response for three patients, but was negative for two and indeterminate for one on a TB immunological test (Table 2). 
Table 1. Clinical characteristics of miliary tuberculosis in our hospital (1).

\begin{tabular}{|c|c|c|c|c|c|c|c|c|}
\hline Case & $\begin{array}{l}\text { Age, } \\
\text { Sex }\end{array}$ & $\begin{array}{l}\text { Smoking } \\
\text { history }\end{array}$ & $\begin{array}{l}\text { Underlying } \\
\text { disease }\end{array}$ & $\begin{array}{l}\text { Detection } \\
\text { method }\end{array}$ & $\begin{array}{c}\text { Diagnosis } \\
\text { on admission }\end{array}$ & $\begin{array}{l}\text { Length from } \\
\text { admission } \\
\text { to diagnosis }\end{array}$ & $\begin{array}{l}\text { Diagnostic } \\
\text { method }\end{array}$ & Region of tuberculosis \\
\hline 1 & $79, \mathrm{M}$ & $(+)$ & CRF,DM & $\begin{array}{l}\text { Clinical symptoms } \\
\text { (Fever) }\end{array}$ & Miliary Tbc (sp) & 7 days & $\begin{array}{c}\text { Bronchoscopy } \\
\text { Cerebrospinal fluid }\end{array}$ & Lung, Meninges, Brain \\
\hline 2 & $48, \mathrm{~F}$ & $(+)$ & SLE (Steroid) & $\begin{array}{c}\text { Clinical symptoms } \\
\text { Fever } \\
\text { Weight loss }\end{array}$ & Miliary Tbc (sp) & 10 days & $\begin{array}{l}\text { Bronchoscopy } \\
\text { Urine }\end{array}$ & Lung, Urinary tract \\
\hline 3 & $73, \mathrm{M}$ & $(+)$ & COPD,GU & $\begin{array}{c}\text { Clinical symptoms } \\
\text { Fever } \\
\text { Headache }\end{array}$ & Miliary Tbc (sp) & 7 days & $\begin{array}{c}\text { Sputum } \\
\text { Cerebrospinal fluid }\end{array}$ & Lung, Meninges \\
\hline 4 & $86, \mathrm{M}$ & $(+)$ & $\begin{array}{l}\text { Sjögren } \\
\text { Syndrome } \\
\text { (Steroid) }\end{array}$ & $\begin{array}{c}\text { Clinical symptoms } \\
\text { Fever } \\
\text { Cough }\end{array}$ & Miliary Tbc (sp) & 7 days & $\begin{array}{l}\text { Bronchoscopy } \\
\text { Urine }\end{array}$ & Lung, Urinary tract \\
\hline 5 & $81, \mathrm{~F}$ & $(-)$ & Liver cirrhosis & $\begin{array}{c}\text { Clinical symptoms } \\
\text { (Fever) }\end{array}$ & $\begin{array}{c}\text { Pulmonary Tbc } \\
\text { (sp) }\end{array}$ & 4 days & $\begin{array}{c}\text { Bronchoscopy } \\
\text { Urine }\end{array}$ & Lung, Urinary tract \\
\hline 6 & $75, \mathrm{~F}$ & $(-)$ & $\begin{array}{l}\text { ANCA related } \\
\text { vasculitis } \\
\text { (Steroid) }\end{array}$ & $\begin{array}{l}\text { Clinical symptoms } \\
\text { Fever } \\
\text { Consciousness } \\
\text { disturbance }\end{array}$ & Pneumonia & 5 days & $\begin{array}{l}\text { Bronchoscopy } \\
\text { Urine } \\
\text { Blood }\end{array}$ & $\begin{array}{l}\text { Lung, Urinary tract } \\
\text { Blood }\end{array}$ \\
\hline
\end{tabular}

CRF: Chronic renal failure, DM: Diabetes mellitus, COPD: Chronic obstructive pulmonary disease, GU: Gastric ulcer.

Table 2. Clinical characteristics of miliary tuberculosis in our hospital (2).

\begin{tabular}{|c|c|c|c|c|c|c|c|c|c|c|}
\hline \multirow[b]{2}{*}{ Case } & \multicolumn{4}{|c|}{ Laboratory findings on admission } & \multirow{2}{*}{$\begin{array}{l}\text { TST } \\
(\mathrm{mm})\end{array}$} & \multicolumn{2}{|c|}{ IGRA } & \multirow[b]{2}{*}{ Complication } & \multirow[b]{2}{*}{ Treatment } & \multirow[b]{2}{*}{ Prognosis } \\
\hline & $\begin{array}{l}\text { WBC } \\
(/ \mu \mathrm{l})\end{array}$ & $\begin{array}{l}\text { Lymphocyte } \\
(/ \mu \mathrm{l})\end{array}$ & $\begin{array}{l}\text { Total protein } \\
(\mathrm{g} / \mathrm{dl})\end{array}$ & $\begin{array}{c}\text { Albumin } \\
(\mathrm{g} / \mathrm{dl})\end{array}$ & & QFT & T-SPOT & & & \\
\hline 1 & 5520 & $442 \downarrow$ & $6.3 \downarrow$ & $2.5 \downarrow$ & N.D. & $\begin{array}{c}(+) \\
(1.68)\end{array}$ & $\begin{array}{l}(+) \\
(15)\end{array}$ & $(-)$ & $\mathrm{INH}+\mathrm{RFP}+\mathrm{EB}$ & $\begin{array}{c}\text { Died } \\
\text { (3 months } \\
\text { later) }\end{array}$ \\
\hline 2 & $10280 \uparrow$ & $308 \downarrow$ & $6.7 \downarrow$ & $3.3 \downarrow$ & $\frac{0 \times 0}{20 \times 15}$ & Indeterminate & ndeterminate & $(-)$ & $\mathrm{INH}+\mathrm{RFP}+\mathrm{PZA}+\mathrm{EB}$ & Good \\
\hline 3 & 6650 & 760 & $6.8 \downarrow$ & $3.0 \downarrow$ & N.D. & $\begin{array}{l}(+) \\
(0.91)\end{array}$ & $\begin{array}{l}(+) \\
(15)\end{array}$ & $(-)$ & $\mathrm{INH}+\mathrm{RFP}+\mathrm{PZA}+\mathrm{EB}$ & Good \\
\hline 4 & $1920 \downarrow$ & $19 \downarrow$ & 7.6 & $2.6 \downarrow$ & $\begin{array}{l}0 \times 0 \\
0 \times 0\end{array}$ & Indeterminate & $\begin{array}{l}(-) \\
(0)\end{array}$ & DIC & $\mathrm{INH}+\mathrm{RFP}+\mathrm{EB}$ & $\begin{array}{c}\text { Died } \\
\text { (1 month } \\
\text { later })\end{array}$ \\
\hline 5 & 5460 & $328 \downarrow$ & $6.9 \downarrow$ & $2.9 \downarrow$ & N.D. & $\begin{array}{c}(+) \\
(5.77)\end{array}$ & $\begin{array}{l}(+) \\
(28)\end{array}$ & $(-)$ & $\mathrm{INH}+\mathrm{RFP}+\mathrm{EB}$ & Good \\
\hline 6 & $10000 \uparrow$ & 718 & $4.7 \downarrow$ & $2.1 \downarrow$ & $\begin{array}{l}0 \times 0 \\
0 \times 0\end{array}$ & $\begin{array}{c}(-) \\
(<0.05)\end{array}$ & $\begin{array}{l}(-) \\
(0)\end{array}$ & $\begin{array}{l}\text { ARDS } \\
\text { DIC } \\
\text { Sepsis }\end{array}$ & $\mathrm{INH}+\mathrm{RFP}+\mathrm{EB}$ & $\begin{array}{c}\text { Died } \\
\text { (2 weeks } \\
\text { later) }\end{array}$ \\
\hline
\end{tabular}

N.D.: Not done, IGRA: Interferon-gamma release assay, QFT: QuantiFERON, TST: Tuberculin skin test, DIC: Disseminated intravascular coagulation, ARDS: Acute respiratory distress syndrome.

Concerning the radiological findings, five of the six patients showed typical findings such as millet-sized nodules in the bilateral diffuse lung field on chest CT. However, because only case 6 showed a diffuse bilateral hilar dominant infiltration shadow and ground-glass opacity on chest CT due to ARDS (Figure 1), it was difficult to obtain a correct diagnosis on admission. 

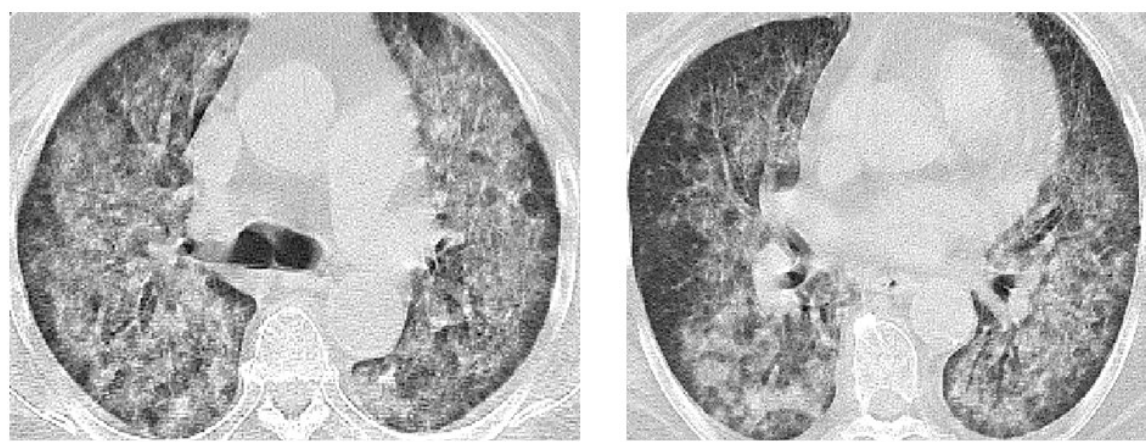

Figure 1. Chest CT on admission (Case 6).

Regarding complications of miliary TB, ARDS was recognized in one patient and disseminated intravascular coagulation (DIC) in two patients. Although treatment according to the guideline of TB disease [3] was performed for all patients after the definite diagnosis, the prognosis was poor and three of the six patients died of miliary TB (Table 2).

\section{Discussion}

The frequency of miliary TB among all TB disease was reported to be $1 \%-2 \%$ in previous reports from Japan and it is severe among TB diseases [4] [5]. The number of miliary TB cases has been increasing recently, often appearing in female and elderly patients [6]. It was recently a higher percentage $(8.3 \%)$ in our tertiary hospital without a TB isolation room. Although malignant disease, human immunodeficiency virus (HIV) infection, diabetes mellitus, renal failure, collagen disease and immunosuppressive treatment are known as risk factors, most of our patients with miliary TB were elderly (average age was 73 years old) and all patients had severe underlying diseases, including three patients receiving immunosuppressive treatments in our tertiary hospital, which many other patients with various underlying diseases visited.

In the clinical symptoms of patients with miliary $\mathrm{TB}$, high fever $\left(\geq 38^{\circ} \mathrm{C}\right)$ was recognized in all patients and it was one detection method of miliary TB as in previous reports. Because miliary TB includes the differential diagnosis of febrile illness [7], we have to check carefully formiliary TB.

Concerning the laboratory findings, lymphocytopenia in the peripheral blood, especially CD4-positive T lymphocytes and hyponutritional conditions such as hypoproteinemia or hypoalbuminemia, were recognized in most patients with miliary TB in this study. It was reported that these two findings were related to the severity of TB disease or the prognosis [8] [9]. The mechanism of lymphocytopenia in the peripheral blood is thought to be a deviation to the inflammation focuses [10], linked to hyponutritional conditions [9] and the influence of treatment for underlying diseases such as autoimmune disorders. Another important finding, IGRAs (QFT-IT and/or T-SPOT) which was useful as a supportive diagnostic marker for TB disease, showed negative or indeterminate results in three of six patients. Because these IGRA responses appeared in patients with 
lymphocytopenia or hypoalbuminemia [11], it was not thought to be useful for the differential diagnosis of miliary TB.

Regarding the radiological findings, although most patients showed typical millet-sized nodules in the bilateral lung field, only case 6 complicated with ARDS showed a diffuse hilar dominant infiltration shadow and ground-glass opacity on chest CT. However, because we usually pay careful attention to the diagnosis of pulmonary TB as the differential diagnosis of pneumonia, all patients get the correct diagnosis of miliary TB within one week. It was reported few patients present as smear-positive in the usual sputum acid-fast bacilli examination [4] [12]. Therefore, we also investigated using the acid-fast bacilli examination using bronchoscopic specimens, peripheral blood, urine, and cerebrospinal fluid as in previous reports.

The treatment according to the guideline of TB disease [3] was immediately started for all six patients after the diagnosis, but three of the six (50\%) died due to complications such as ARDS and/or DIC and worsening of miliary TB. Although the mortality rate of patients with miliary TB has been reported to be high $(\geq 20 \%)$ and the prognosis poor [13] [14], it showed a higher percentage in our study. Most patients in our study did not have periodical radiological examinations for a long time during the follow-up period of underlying disease in other departments of our hospital, or at other local hospitals as outpatients. Therefore, the delay in detection may be linked to the prognosis despite the short duration from admission to diagnosis. The complications of miliary TB consisted of DIC in two patients and ARDS in one patient. Nagai et al. also reported that $5.4 \%$ of miliary TB was complicated with ARDS and $12.2 \%$ was complicated with DIC and that these complications became poor prognosis factors [4].

Although there are a few reports suggesting that the administration of corticosteroid drugs is effective for the treatment of ARDS complicated with miliary TB [15] [16] [17], they were not effective for case 6 in this study. Therefore, we have some doubts regarding the effectiveness of corticosteroid drugs administration for miliary TB.

There are some limitations in this study. Firstly, a small number of miliary TB patients were included in this study and they were geographically restricted to a small area in Japan with an intermediate TB population. We hope that a large scale nationwide study will be performed in Japan. Secondly, although HIV testing was not performed for all patients with TB disease, all patients with miliary TB showed negative responses for HIV and HIV infection was not related to the occurrence of miliary $\mathrm{TB}$.

\section{Conclusion}

Because the prognosis of patients with miliary TB was poor and showed a rapidly progressive clinical course in this study, it is thought to be important to perform bronchoscopic examinations proactively in combination with other common hospitals or other departments in the same hospital for patients suspected 
of miliary TB to obtain an appropriate early diagnosis and start treatment.

\section{Conflict of Interest}

There are no conflicts of interests regarding this manuscript.

\section{References}

[1] Centers for Disease Control and Prevention (2014) Reported Tuberculosis in the United States. Atlanta.

[2] Tomashefski, J.F., Cagle, P.T., Farver, C.F. and Fraire, A.E. (2008) Dail and Hammar's Pulmonary Pathology. 3rd Edition, Springer, New York.

[3] Blumberg, H.M. (2003) American Thoracic Society/Centers for Disease Control and Prevention/Infectious Diseases Society of America: Treatment of Tuberculosis. American Journal of Respiratory and Critical Care Medicine, 167, 603-662. https://doi.org/10.1164/rccm.167.4.603

[4] Nagai, H., Kurashima, A., Akagawa S., et al. (1998) Clinical Analysis of Military Tuberculosis. Kekkaku, 73, 611-617. (In Japanese)

[5] Hiratsuka, T., Arimura, Y. and Ihi, T. (2004) A Clinical Study of Military Tuberculosis. Nippon Kansensyo Gakkai Zasshi, 78, 929-934. (In Japanese) https://doi.org/10.11150/kansenshogakuzasshi1970.78.929

[6] Akagawa, S. (2013) Military Tuberculosis: A Wide Variety of Radiological and Clinical Findings. Nippon Kokyuuki Gakkai Zasshi, 2, 513-520. (In Japanese)

[7] Gelfand, J.A. (1994) Fever, Including Fever of Unknown Orifgin. In: Isselbacher, K.J., Ed., Harrison's Principles of Internal Medicine, 13th Edition, McGraw-Hill, New York, 81.

[8] Morris, C.D., Bird, A.R. and Nell, H. (1989) The Hematological and Biochemical Changes in Severe Pulmonary Tuberculosis. An International Journal of Medicine, 73, 1151-1159.

[9] Jones, B.E., Oo, M.-M., Taikwel, E.K., et al. (1997) CD4 Cell Counts in Human Immunodeficiency Virus-Negative Patients with Tuberculosis. Clinical Infectious Diseases, 24, 988-991. https://doi.org/10.1093/clinids/24.5.988

[10] Harada, Y., Takamoto, M., Harada, S., et al. (1988) Lymphocyte Subsets by Monoclonal Antibodies and Flow Cytometry in Patients with Pulmonary Tuberculosis. Kekkaku, 63, 41-50. (In Japanese)

[11] Komiya, K., Ariga, H., Nagai, H., et al. (2010) Impact of Peripheral Lymphocyte Count on the Sensitivity of 2 IFN- $\gamma$ Release Assays, QFT-G and ELISPOT, in Patients with Pulmonary Tuberculosis. Internal Medicine, 49, 1849-1855. https://doi.org/10.2169/internalmedicine.49.3659

[12] Ogawa, K., Taniguchi, H., Nakajima, Y., et al. (1988) Clinical Observation of 15 Cases with Military Tuberculosis. Kekkaku, 63, 247-253. (In Japanese)

[13] Hussain, S., Irfan, M., Abbasi, M., et al. (2004) Clinical Characteristics of 110 Military Tuberculosis Patients from a Low HIV Prevalence Country. The International Journal of Tuberculosis and Lung Disease, 8, 493-499.

[14] Sharma, S.K., Mohan, A., Sharma, A. and Mitra, D.K. (2005) Military Tuberculosis: New Insights into an Old Disease. The Lancet Infectious Diseases, 5, 415-430. https://doi.org/10.1016/S1473-3099(05)70163-8

[15] Deng, W., Yu, M., Ma, H., et al. (2012) Predictors and Outcome of Patients with Acute Respiratory Distress Syndrome Caused by Military Tuberculosis: A Retrospective Study in Chongqing, China. BMC Infectious Diseases, 12, 121-126. 
https://doi.org/10.1186/1471-2334-12-121

[16] Lee, K., Kim, J.H., Lee, W.Y., et al. (2011) Acute Respiratory Distress Syndrome Caused by Military Tuberculosis: A Multicenter Survey in South Korea. International Journal of Tuberculosis and Lung Disease, 15, 1099-1103.

https://doi.org/10.5588/ijtld.10.0557

[17] Wallis, R.S. (2005) Reconsidering Adjuvant Immunotherapy for Tuberculosis. Clinical Infectious Diseases, 41, 201-208. https://doi.org/10.1086/430914

Submit or recommend next manuscript to SCIRP and we will provide best service for you:

Accepting pre-submission inquiries through Email, Facebook, LinkedIn, Twitter, etc. A wide selection of journals (inclusive of 9 subjects, more than 200 journals)

Providing 24-hour high-quality service

User-friendly online submission system

Fair and swift peer-review system

Efficient typesetting and proofreading procedure

Display of the result of downloads and visits, as well as the number of cited articles

Maximum dissemination of your research work

Submit your manuscript at: http://papersubmission.scirp.org/

Or contact jtr@scirp.org 